\title{
LEAD POISONING IN DOG - CASE REPORT
}

\author{
Mariana Isa Poci Palumbo ${ }^{1}$, Luiz Henrique de Araújo Machado ${ }^{1}$, Michiko Sakate ${ }^{1}$, \\ Daniela Fregni Caetano ${ }^{1}$, Didier Quevedo Cagnini ${ }^{1}$, Renée Laufer Amorim ${ }^{1}$, \\ Regina Kiomi Takahira ${ }^{1}$
}

1 Universidade Estadual Paulista (UNESP) - Campus de Botucatu - palumboma11@yahoo.com.br

\begin{abstract}
The present study reports the occurrence of lead poisoning in a male, 2 year-old mongrel dog attended at UNESP Botucatu Veterinary Hospital. The animal was brought to the hospital with claim of gastrointestinal and nervous disturbs for 10 days, worsening in the last 24 hours. After unsuccessfully attempts to control status epileticus, the animal died. Hematological evaluation revealed significant rubricytosis and basophilic stippling, highly suggestive of lead poisoning. Serum lead concentration confirmed toxic levels of this element. Necropsy evidenced the presence of foreign bodies in stomach (one stone and two metallic objects) and, microscopically, characteristic inclusions in renal parenchyma. Fragments obtained from liver and kidneys revealed lead concentrations of $0,8 \mu \mathrm{g} / \mathrm{g}$ and $25 \mu \mathrm{g} / \mathrm{g}$, respectively, which in association to clinical signs of saturnism, determined the diagnosis of lead poisoning.
\end{abstract}

Key words: canines; toxicology

\section{INTOXICAÇÃO POR CHUMBO EM UM CÃO - RELATO DE CASO}

RESUMO: O presente trabalho relata a ocorrência de intoxicação por chumbo em um canino macho, sem raça definida, de dois anos de idade, atendido pelo Hospital Veterinário da UNESP de Botucatu. $\mathrm{O}$ animal veio para o atendimento com histórico de distúrbios neurológicos e gastrointestinais, com início do quadro há dez dias e piora nas últimas 24 horas. O cão veio a óbito após tentativas frustradas de controlar o status epileticus. A avaliação hematológica revelou marcante rubricitose e ponteados basofílicos, altamente sugestivos de intoxicação por chumbo. A concentração sérica de chumbo confirmou níveis tóxicos desse elemento. A necropsia mostrou a presença de três corpos estranhos estomacais (uma pedra e dois objetos metálicos) e, na microscopia, inclusões características em parênquima renal. Fragmentos obtidos de fígado e rins, que revelaram concentrações plúmbicas de $0,8 \mu \mathrm{g} / \mathrm{g}$ e $25 \mu \mathrm{g} / \mathrm{g}$, respectivamente, valores que, associados aos sinais clínicos da doença, firmam o diagnóstico de intoxicação por chumbo.

Palavras-chave: caninos; toxicologia 


\section{INTRODUCTION}

Lead (or plumbus) is a metal found in the nature in free state or in composition with a variety of elements (Cordeiro e Lima Filho, 1995). Because of its low point of fusion and high maleability, lead was one of the first metals manipulated by men and, consequently, one of the first known toxic compounds (Cordeiro e Lima Filho, 1995; Hueza et al., 2008). Because it is highly resistant to atmospheric corrosion and to the effects of acids, specially sulphuric acid, lead is commonly used in construction materials, batteries, chemical products, tubes, cables, paintings among others (Caldeira et al., 2000).

Health risks associated to lead exposure were verified at least 2000 years ago (Spinola et al., 1980; Windebank, 1993). Unlike other elements - as iron, zinc, cobalt, chrome, manganese and copper - lead is an element absolutely estrange to animal metabolism in any quantity. It is considered a neurotoxin which presence above a critical concentration in diverse tissues interferes with metabolic pathways, causing clinical signs of the disease known as saturnism or lead poisoning (Cordeiro e Lima Filho, 1995).

The absorption of lead by digestive organs depends mainly on dietary factors, as the state of fasting, ingestion of proteins and the presence of calcium, iron and phosphorus. A deficiency of those elements enhances lead absorption and vice-versa, probably due to competition for a common mechanism of transport (Sadao, 2002). It is important to remember that young animals absorb higher quantities of lead than adult individuals, because of particularities of enterocytes during growing age, similarly to what is observed in humans (Hueza et al., 2008).
International literature presents many studies on the effects of lead poisoning in the organism, demonstrating that multiple organs may be affected (Moreira e Moreira, 2004). When lead achieves peripheral circulation, it accumulates in liver, spleen, kidneys, heart, lungs, brain, muscles and skeleton, and the main deleterious effects are manifested by hematological, nervous, renal, gastrointestinal and reproductive functions (Jacob et al., 2002). Neurological alterations include seizures, aggressiveness and temperament alterations (McLeavey, 1977).

In order to prevent the occurrence of poisoning, it is necessary to avoid contact of the animals with lead containing products, with possibly contaminated ground, as places where there were industries or battery deposit, and areas next to those (Hueza et al., 2008).

The animals are important sentinels to detect lead poisoning in humans and this makes the correct diagnosis even more important (Lange et al., 2003). The aim of the present study is to report a case of lead poisoning in a male, 2 year-old mongrel dog attended at UNESP Botucatu Veterinary Hospital.

\section{MATERIAL AND METHODS}

A male, two year-old mongrel dog was brought to the Veterinary Hospital at UNESP Botucatu with claim of neurological (agitation, vocalization, head-pressing and seizures) and gastrointestinal (hyporexia and sialorrhea) disturbs for 10 days, significantly worsening in the last 24 hours. The animal was not vaccinated for infecto-contagious diseases and was in contact with two asymptomatic dogs. The animal was fed homemade food ad 
libitum and the owner reported its tendency to eat many objects.

The animal was presented in status epileticus and intravenous treatment with diazepam and phenobarbital was instituted with four injections at 20 minutes intervals, without complete remission of seizures. Because seizures were refractory to this protocol, intravenous thiopental was used to maintain the animal sedated.

Physical examination evidenced pale ocular and oral mucosas, discreet crepitation in lung fields and significant tension of mandibular muscles. Hematological evaluation revealed normocytic normochromic anemia with marked rubricytosis (150 metarubricytes/100 leukocytes), presence of basophilic stippling (Figure 1), anisocytosis, polychromasia, neutrophilic leukocytosis and monocytosis.

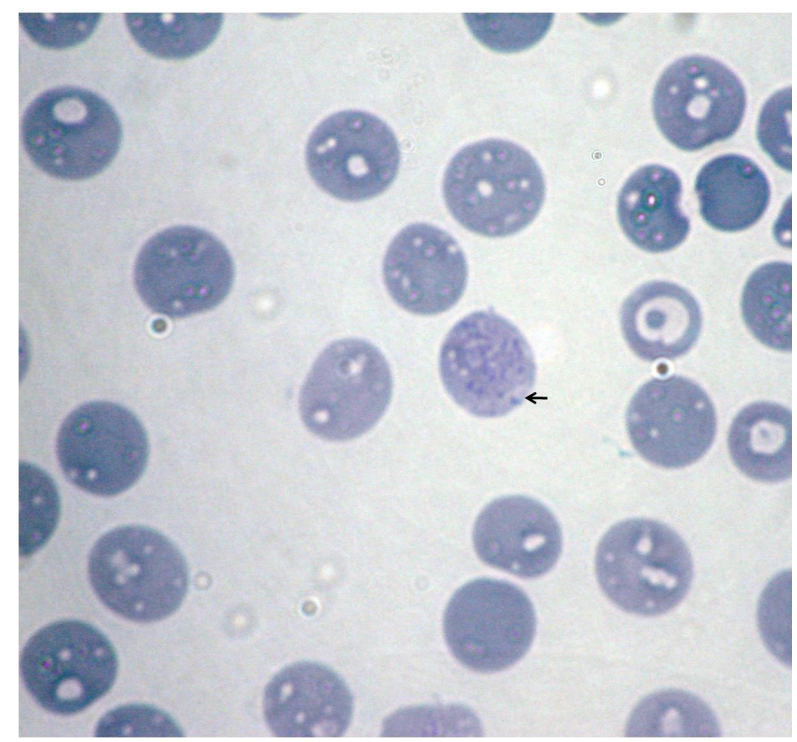

Figure 1- Blood smear: basophilic stippling in a red blood cell (arrow).

After this hematological findings of rubricytosis and basophilic stippling highly suggestive of lead poisoning, the owners were questioned in order to establish a possible source of contamination to confirm the suspect diagnosis. The owner reported that the dog used to gnaw the walls and that, approximately one month before, her husband left an opened motorcycle battery exposed to the animal for some time.

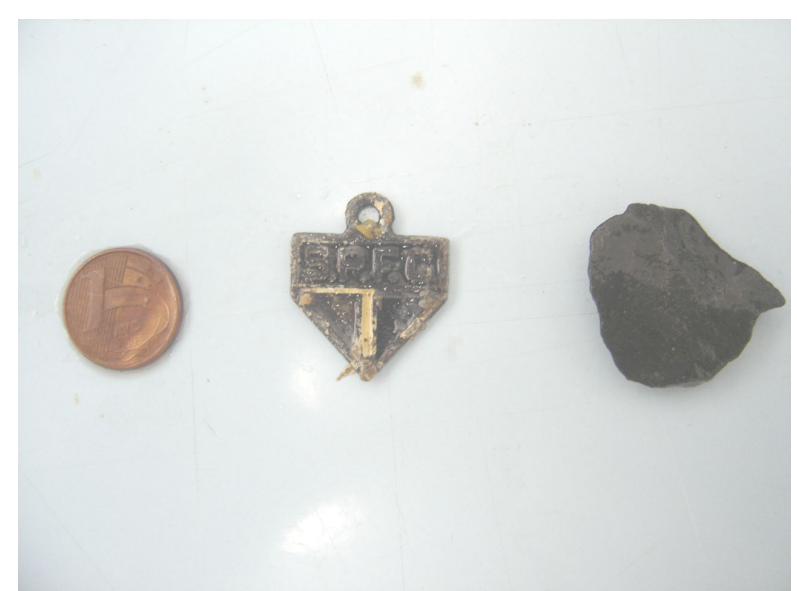

Figure 2 - Foreign bodies found in patient's stomach.

In order to confirm the diagnostic suspect, blood samples were sent to the Center of Toxicological Assistance of the University (CEATOX) and the serum lead dosage was $25 \mu \mathrm{g} / \mathrm{dl}$. After $6 \mathrm{~h}$ of anesthesia and some unsuccessful attempts to let the animal awake without seizures, the animal died.

Necropsy evidenced cyanotic mucosas and the classical lead line in the gums. There were also extensive focal areas of congestion in lungs, liver congestion, paleness of heart and kidneys, mild gastroenteritis and presence of foreign bodies in stomach (Figure 2). Microscopy revealed congestion, significant alveolar edema (Figure 4) and emphysema in lungs and congestion, trabecullar displacement and degeneration of hepatocytes. Kidneys presented protein in Bowman space (Figure 3), degeneration and acute tubular necrosis, and hemoglobinuria. Central nervous system presented necrosis of subcortical white substance, pronounced gliosis, chromatolysis, satellitosis and intense Wallerian degeneration. Death was attributed to respiratory insufficiency and the main process was probable exogenous intoxication. 


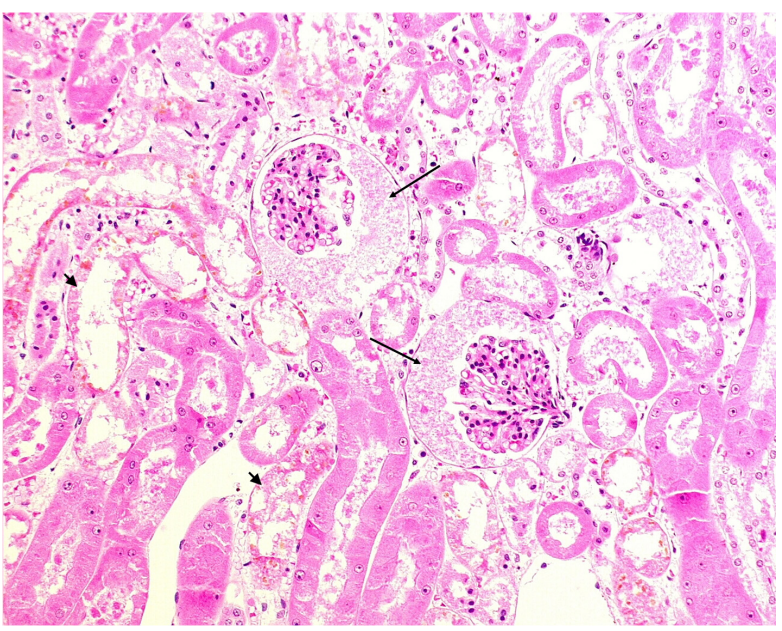

Figure 3 - Kidney. Large arrow: protein content in glomeruli. Small arrow: tubular degeneration. Hematoxylin-Eosin staining. Obj 20x.

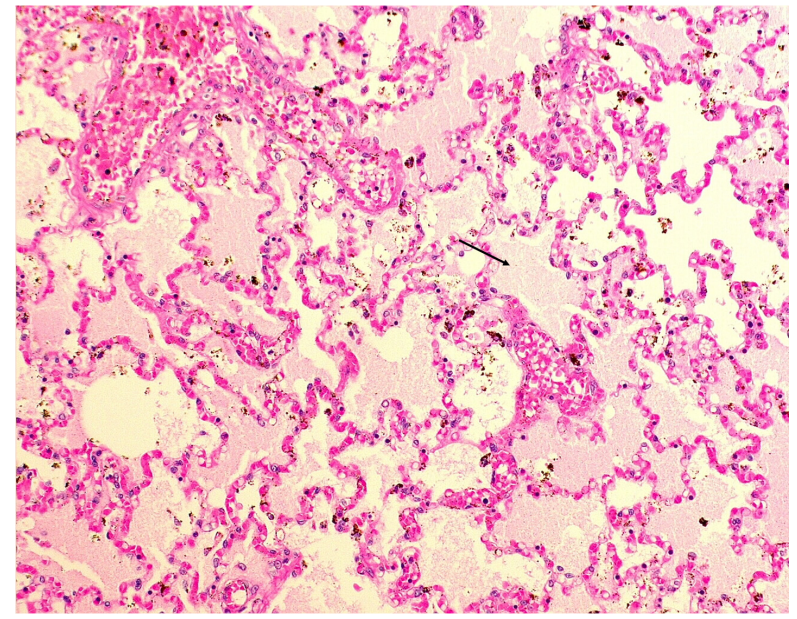

Figure 4 - Lung. Arrow: pronounced alveolar edema. Hematoxylin-Eosin staining. Obj 20x.

Tissue fragments were also sent to toxicological analysis and lead concentrations of $0.8 \mu \mathrm{g} / \mathrm{g}$ and $25 \mu \mathrm{g} / \mathrm{g}$, were obtained for liver and kidneys, respectively. These values, associated to clinical signs and necropsy findings, confirm the diagnosis of lead poisoning.

\section{RESULTS AND DISCUSSION}

Both in companion and production animals, lead poisoning is usually manifested acutely and the chronic disease is rarely observed (Hueza et al., 2008). In the present report, the symptoms have initiated 10 days before and worsened in the last 24 hour.

Most animals acutely poisoned manifest nervous (encephalopathy) and also gastrointestinal symptoms. In pets, nervous signs include behavioral alterations, apathy, ataxia, nystagmus, opistotonus, seizures and, in some cases, blindness (Hueza et al., 2008). In the present report, the animal presented both neurological (agitation, vocalization, head-pressing and seizures) and gastrointestinal (hyporexia and sialorrhea) signs.

Literature evidences the occurrence of neurophysiologic disturbs caused by lead exposure in children, including deficits of attention, concentration, memory, intelligence, learning, language and psychomotor behavior, growing disturbs and endocrine effects of varying degrees (Lanphear et al., 2000; Schnaas et al., 1999; Wasserman et al., 1993). In the present case it was not possible to observe if the dog would present signs of those alterations because it has been sedated and died in few hours.

Hematological evaluation revealed marked rubricytosis metarubricytes/100 leukocytes), presence of basophilic stippling, anisocytosis, polychromasia, neutrophilic leukocytosis and monocytosis, which are important in the case of suspect lead poisoning.

The most indicated laboratory exam in the diagnosis of lead poisoning is the detection of this element in feces, urine, milk and, specially, in heparinized blood (Hueza et al., 2008). Samples of blood, liver and kidneys were sent to CEATOX for lead dosage and values obtained were above acceptable limits, specially considering that lead is always exogenous and does not participate in metabolic functions. Those values, associated to necropsy findings made possible to confirm the diagnosis of lead poisoning.

Though radiological exam it is possible to observe lead lines in long bone metaphysis of poisoned animals and this may be an additional tool to 
conclude diagnosis (Knight and Kumar, 2003), but in the present case this exam was not performed.

In small animals, it is necessary to differentiate lead poisoning from rabies, nutritional deficiencies that cause neurological alterations and, in dogs, from canine distemper (Hueza et al., 2008). The animal in the present case was not vaccinated for infectious diseases, but it was in contact to two asymptomatic dogs and necropsy did not evidence signs of infectious diseases.

Among environmental pollutants, lead is being considered by several authors as the inorganic element that offer more risk to production animals health, particularly for bovine herds (Marçal et al., 1999; Marçal and Trunkl, 1994), that may be exposed by ingestion of contaminated grass, water or mineral formulations (AAFCOI, 1993; Marçal et al., 1998).

Industrial use of lead is extensive, but the production of batteries represents, probably, the larger consume of this substance in developing countries (Araujo et al., 1999; Jacob et al., 2002). In the present case, the owner informed that the animal used to gnaw the walls and that one month before the animal was exposed to an opened motorcycle battery. Foreign bodies found in stomach were probably the source of poisoning.

According to the literature, microscopic examination of tissues demonstrates the presence of neuronal necrosis, Purkinje cells degeneration, astrocyte proliferation and demyelination of peripheral nerves in nervous system and the presence of inclusion corpuscles in renal, hepatic and splenic cells (Hueza et al., 2008). Macro and microscopic alterations reported in the present case were compatible to the suspect of lead poisoning.

\section{CONCLUSION}

The case reported in the present study shows interesting and challenging aspects. The clinical signs are nonspecific, what could make difficult to determine diagnosis. Although during anamnesis the clinicians have already suspected of lead poisoning.

Early diagnosis of lead poisoning in animals is very important, as the source of contamination may be the same for humans, and animals may be used as sentinels to detect human exposure and help in early diagnosis and successful treatment.

Due to multisystemic character of lead poisoning, one should always suspect this disease when animals present neurological alterations and should use diagnostic methods associating observations of blood count, serum dosage and, if it is the case, necropsy.

\section{REFERENCES}

ARAUJO, U.C.; PIVETTA, F.R.; MOREIRA, J.C. Avaliação da exposição ocupacional ao chumbo: proposta de uma estratégia de monitoramento para prevenção dos efeitos clínicos e subclínicos. Cadernos de Saúde Pública, v.15, n.1, p.123-131, 1999.

ASSOCIATION OF AMERICAN FEED CONTROL OFFICIALS INCORPORED (AAFCOI). Official guidelines for contaminant levels permitted in mineral feed ingredients. Indiana, 1993.

CALDEIRA, C.; MATTOS, R.C.O.C.; MEYER, A. et al. Limites da aplicabilidade da determinação do ácido $\Delta$-aminolevulínico urinário como teste screening na avaliação da intoxicação profissional pelo chumbo. Caderno de Saúde Pública, v.16, n.1, p.225-230, 2000.

CORDEIRO, R.; LIMA-FILHO, E.C. A inadequação dos valores dos limites de tolerância biológica para a prevenção da intoxicação profissional pelo chumbo no Brasil. Caderno de Saúde Pública. v.11, n.2, p.177186, 1995. 
HUEZA, I.M.; SANTÁNA, M.G.; NETO, J.P. Toxicologia do chumbo, mercúrio, arsênio e de outros metais. In: SPINOSA, H.S.; GORNIAK, S.L.; NETO, J.P. Toxicologia aplicada à medicina veterinária, Barueri: Manole, p.641665, 2008.

JACOB, L.C.; ALVARENGA, K.F.; MORATA, T.C. Os efeitos da exposição ocupacional ao chumbo sobre o sistema auditivo: uma revisão da literatura. Revista Brasileira de Otorrinolaringologia, v.68, n.4, p.564-569, 2002.

KNIGHT, T.E.; KUMAR, M.S.A. Lead toxicosis incats - a review. Journal of Feline Medicine and Surgery, v.5, p.249-255, 2003.

LANGE, J.H.; LaPORTE, R.E.; CHANG, Y.F. Exposure to lead and an old way of counting. Environmental Health Perspectives, v.11, n.10, p.501-510, 2003.

LANPHEAR, B.P.; DIETRICH, K.; AUINGER, P. et al. Cognitive deficits associated with blood lead concentrations $<10 \mathrm{mg} / \mathrm{dl}$ in US children and adolescents. Public Health Reports, v.115, n.6, p. 521-29, 2000.

MARÇAL, W.S.; CAMPOS NETO, O. NASCIMENTO, M.R.L. Valores sanguíneos de chumbo em bovinos Nelore suplementados com sal mineral naturalmente contaminado por chumbo. Ciência Rural, v.28, n.1, p.53-57, 1998.

MARÇAL, W.S.; GASTE, L.; LIBONI, M. et al. Lead Concentration in mineral salt mixtures used in beef cattle food supplementation in Brazil. Veterinarski Arhives, v.69, n.6, p.349-355, 1999.
MARÇAL, W.S.; TRUNKL, I. Poluição industrial na zona rural: implicações na saúde pública. In: CONGRESSO BRASILEIRO DE MEDICINA VETERINARIA, 1994, Olinda, Anais... Olinda: Spemve, p.656, 1994.

MCLEAVEY, B.J. Lead poisoning in dogs. New Zealand Veterinary Journal, v.25, p.395-6, 1977.

MOREIRA, F.R.; MOREIRA, J.C. A cinética do chumbo no organismo humano e sua importância para a saúde. Ciência e Saúde Coletiva, v.9, p.167-81, 2004.

SADAO, M. Intoxicação por chumbo. Revista de Oxidologia, p.37-42, 2002.

SCHNAAS L.; ROTHENBERG S.J.; PERRONI, $E$. et al. Relación entre La exposición prenatal y postnatal al plomo y el desarrollo intelectual Del niño a los 42 meses da edad. Perinatology y Reproducción Humana, v.13, n.3, p.214-20, 1999.

SPÍNOLA, A.G.; FERNÍCOLA, N.A.G.G.; MENDES, R. Intoxicação profissional pelo chumbo, In: Medicina do trabalho - doenças profissionais, São Paulo: Sarvier, p.437-460, 1980.

WASSERMAN, G.A.; GRAZIANO, J.H.; FACTOR-LITVAK, P. et al. Consequences of lead exposure and iron supplementation on childhood development at age 4 years.

Neurotoxicology and Teratology, v.16, n.3, p. 233-40, 1993.

WINDEBANK, A.J. Metal neuropathy. In: DYCK, P.J. et al. Peripheral Neuropathy, 3.ed, Philadelphia: W.B. Saunders Co., p.1549-1570, 1993. 
This document was created with Win2PDF available at http://www.win2pdf.com. The unregistered version of Win2PDF is for evaluation or non-commercial use only. This page will not be added after purchasing Win2PDF. 